\title{
Features of Formation of Marketing Relations of Non- Profit Organizations in Modern Conditions
}

\author{
E.S. Akopova ${ }^{1}$ N.V. Przhedetskaya ${ }^{1}$ V.V. Sheveleva ${ }^{1, *}$ A.T. Giyasov ${ }^{2}$ \\ ${ }^{I}$ Rostov state economic university (RINH),Rostov-on-Don 344002, Russian Federation \\ ${ }^{2}$ Kyzyl-Kya Multiprofile Institution, Batken State University, Batken city, Batken region, Kyrgyzstan \\ ${ }^{*}$ Corresponding author. Email: beloveronika @yandex.ru
}

\begin{abstract}
Health care is one of the key areas of the national economy, which largely determines the standard of living of the population. In modern Russia, in the context of large-scale transformational market processes, this sphere is the subject of serious changes associated with emergencies and the intensive development of private medical organizations, on the one hand, and a review of the fundamentals of the functioning of public health organizations, on the other. In this case, very significant contradictions arise in this area, which will be investigated in this article.
\end{abstract}

Keywords: health care, marketing of medical organizations, medical services, private and public health organizations, market segmentation, marketing mix, medical services

\section{INTRODUCTION}

The first contradiction is related to the fact that medical services, which are traditionally treated as public goods, are transferred to the sphere of economically profitable ones. That is why even without the possibility of obtaining medical services on a paid basis and knowing about the existing opportunities, consumers are interested in receiving free medical services from public health organizations, but under the condition of high quality and service, which, however, is difficult to implement due to the reduction in funding for these organizations.

The second contradiction is that there is a growing number of consumers with above-average incomes who can pay for commercial medical services provided by private medical organizations.

This causes growing dissatisfaction with the activities of public health organizations and a decrease in interest in the effect of the compulsory health insurance system, the abolition of which makes all medical services commercial and, thus, inaccessible to disadvantaged groups. [1]

Based on this, we can judge that the development of marketing of medical organizations is becoming more popular in modern Russia, but at the same time, it faces certain problems that require attention and search for a new means of solving them, taking into account the priority of the health sector for the socio-economic system. According to a sociological survey conducted by the allRussian center for public opinion research in 2018, the majority of the population considers the low level of health care development to be the most serious problem in modern Russia.

A survey by the Russian Public Opinion Research Center conducted in 2017 found that only $9 \%$ of Russians have a positive view of the current situation in the health sector, while $52 \%$ believe that the situation in this area is critical. Key health issues include the following:

- low level of service in public health organizationsdifficulty in organizing doctor's appointments, long queues, inattention and disrespectful attitude of medical staff $(56 \%)$;

- low level of professionalism of medical workersincorrect diagnosis and negative result of treatment (37\%);

- price inaccessibility of medical devices and services and their deficit (35\%);

- high level of moral and physical deterioration of medical technologies, as well as equipment, lack of necessary medical materials and medicines (31\%). [2]

According to another sociological study conducted by the Russian Public Opinion Research Center in 2018, the majority of modern Russian consumers (46\%) prefer to use the services of public health organizations, many $(35 \%)$ prefer self-treatment, while the minimum share $(11 \%)$ use the services of private (commercial) health organizations. [2]

According to the report on global competitiveness for 2017-2018, prepared within the framework of the World Economic Forum, Russia ranks 93rd among 137 countries in terms of life expectancy (70.9 years ), which indicates that the situation in the health sector is not favorable enough. [3]

Based on all of the above, the following main conclusions can be drawn:

- currently, there is a crisis in the Russian healthcare system, which is also caused by the low marketing activity of Russian healthcare organizations;

- a promising way to overcome the Russian crisis in the health care system is to activate the marketing activities of organizations in this area;

- there is a clear opposition between public and private healthcare organizations that have certain 
marketing advantages and disadvantages, which does not allow for full and effective satisfaction of the demand of Russian consumers for medical products and services. [4] As a result of studying the practice of functioning of the modern Russian market of medical services, it is possible to identify interesting trends in development:

1. Almost all modern Russian healthcare organizations, not only private (commercial), but also public (non-commercial), form a website that contains current information about the organization's activities and its competitive advantages. The Internet site of health organizations is usually used as an opportunity to collect feedback, which often takes the form of consumer reviews and can be accessed by everyone.

This is why the website is an important element of the image of modern Russian healthcare organizations. Private healthcare organizations conduct marketing programs to maintain their clientele by providing personal loyalty cards with discounts on various medical services.

2. Development of marketing of medical devices and services. Innovative medical services are promoted in the market through marketing. State (non-profit) healthcare organizations publish information on modern innovative medical services on their website in order to support their competitiveness. Private (commercial) healthcare organizations also post information about innovative medical services on their websites and have automatic newsletters for their target audience, which include product offers for innovative medical services.

3. Development of personal marketing (marketing of medical professionals). [5]

Competition in the Russian market of medical services is present both at the level of health care organizations and at the level of medical professionals who are interested in creating their own client base (in order to maximize their income) and improve their image (for a career in public health organizations). For this purpose, specialized Internet platforms, forums, ratings, etc. are created where consumers leave reviews and evaluate the work of medical personnel. [6]

Despite the desire to form a socially oriented market economy, modern economic systems are strongly focused on business and profit-making, which, first, indicates the establishment and maintenance of a high level of competition in most industry markets.

In an effort to intensify business activity, the state reduces barriers to market entry to a minimum, and creates and maintains favorable conditions for business development. Competition is constantly growing among both domestic and foreign business structures.

Second, the business orientation of the modern economy is manifested in the dominance of commercial goals and values. The current market is dominated by an ideological platform in which modern economic systems and almost all their participants are more or less focused on making profits and getting private advantages - while public interests are slowly but inevitably taking a back seat. Commercial criteria (profit, return on investment, and return on investment) are becoming the most important benchmarks for making business decisions. [7]

Third, in a modern business-oriented economy, the state seeks to minimize the level of its interference in economic processes.

The era of state paternalism is passing away, giving way to market self-government. Privatization has opened up opportunities for the dominance of private property in the modern economy and progress in this area encourages an increasing rejection of state property in favor of private management, which leads to higher efficiency and as a result makes it more preferable.

As a result of a comprehensive analysis of the cause-andeffect relationships of the impact of business-oriented Economics on the marketing activities of non-profit organizations in modern Russia, the following key factors of this process can be identified, as well as the tasks and priorities of marketing of non-profit organizations (table $1)$.

Table 1 New challenges and priorities for marketing non-profit organizations in the modern business-oriented economy [8]

\begin{tabular}{|l|l|l|}
\hline \multicolumn{1}{|c|}{ Key factors } & \multicolumn{1}{|c|}{$\begin{array}{c}\text { Problems of oriented business } \\
\text { economy }\end{array}$} & \multicolumn{1}{|c|}{$\begin{array}{c}\text { New marketing priorities for a } \\
\text { nonprofit organization }\end{array}$} \\
\hline $\begin{array}{l}\text { Modernization of the } \\
\text { institutional environment }\end{array}$ & $\begin{array}{l}\text { Transformation of social benefits } \\
\text { into economic benefits }\end{array}$ & $\begin{array}{l}\text { Increasing attention to current } \\
\text { market demand trends }\end{array}$ \\
\hline $\begin{array}{l}\text { The liberalization of } \\
\text { commercial activities }\end{array}$ & $\begin{array}{l}\text { Increasing competition from the } \\
\text { trade organization }\end{array}$ & $\begin{array}{l}\text { Priority is shifted to the } \\
\text { competitiveness } \\
\text { process }\end{array}$ \\
\hline $\begin{array}{l}\text { Formation of a consumer } \\
\text { society }\end{array}$ & $\begin{array}{l}\text { Changing values in favor of } \\
\text { commercial parameters }\end{array}$ & $\begin{array}{l}\text { The focus is on the formation of } \\
\text { social responsibility of employees }\end{array}$ \\
\hline Crisis deficit of the state budget & The reduction of funding & $\begin{array}{l}\text { The importance of attracting } \\
\text { financial resources in the process of } \\
\text { marketing actions }\end{array}$ \\
\hline $\begin{array}{l}\text { Globalization, technology } \\
\text { progress }\end{array}$ & $\begin{array}{l}\text { Growth of the resource potential of } \\
\text { the state benefits provided }\end{array}$ \\
\hline $\begin{array}{l}\text { Rationalization of the state 's } \\
\text { economic work }\end{array}$ & $\begin{array}{l}\text { Setting marketing goals for a non- } \\
\text { profit organization }\end{array}$ & $\begin{array}{l}\text { The priority goal is to make a profit } \\
\text { and self-financing }\end{array}$ \\
\hline
\end{tabular}


As can be seen from table 1, we have identified four key factors in the business-oriented economy that affect the marketing activities of non-profit organizations in modern Russia.

The first factor is the modernization of the institutional environment. The Institute for providing state benefits , which was the main one in Russia until the transition period of the 1990s, has been transformed, and is now considered as an alternative to the Institute for providing economic benefits.

Modern Russian legislation provides or creates opportunities for providing goods and services on commercial terms that are traditionally considered unattractive for private business and not suitable for individual use by consumers-from providing educational services at all levels of the education system and providing medical services to toll roads, beaches, parks, etc.

Under the influence of these institutional changes associated with creating conditions for obtaining commercial advantages, transformation from public goods to economic ones, the level of quality requirements on the part of modern consumers is becoming higher. For example, in the field of medical services. And this is due to the fact that when this area was related to public goods at the end of the XX century, consumers ' demands were reduced to the timely provision of medical services and the very possibility of receiving them. [9]

In the XXI century, medical services are considered costeffective - and modern Russian consumers prefer paid medical services provided by private commercial health care organizations. This is due to convenience (no queues, better work schedules, etc.) and more thorough work by medical professionals (due to higher wages and time allocated for patient examinations).

At the same time, public health organizations that provide medical services under the terms of compulsory health insurance - that is, free of charge for patients - are becoming less popular and have to introduce innovations in their activities, for example, conducting marketing research to improve their performance. That is a priority issue for them is the manifestation of increased attention to the current demand trends.

The second factor is the liberalization of commercial activity. The peculiarity of modern Russia is an attempt to ensure the possibility of private commercial entrepreneurial initiative in all areas of the national economy, including those areas that have traditionally specialized in providing public services.

In this regard, the share of private business structures in Russia in 2018 was $86.3 \%$, an increase of $15 \%$ compared to 2000 , when it was $75 \%$. [9]

This trend has led to increased competition from commercial organizations and caused the need to implement a system for managing the competitiveness of non-profit organizations in the process of marketing activities.

The third factor is the formation of a consumer society. Under the influence of the two above-mentioned trends, a consumer society has already been formed in Russia, in which commercial companies influence the value attitudes of consumers, forming artificial needs, due to which material motives and incentives for work are created. Changing the cost settings in favor of the commercial environment in society as a whole complicates the process of attracting socially responsible employees to non-profit organizations.

Modern employees often seek to show social responsibility, but the problem is not high enough wages provided by non-profit organizations.

The fourth factor is the state budget deficit caused by the crisis of the Russian economy, which began in 2009 under the influence of the global financial crisis, which manifests itself at all levels of the budget system of the Russian Federation. According to statistical data from the Federal State Statistic Service, in 2017, Federal budget revenues and budgets of the Russian regions amounted to 31,046. 7 billion rubles (33.7\% of GDP), while expenditures amounted to 32,395. 7 billion rubles (35.2\% of GDP). [10] That is, the budget deficit of 1.349 billion rubles. $(1.5 \%$ of GDP), which inevitably leads to a reduction in funding for non-profit organizations.

The fifth factor is globalization and technological progress. The availability of information about leading technical achievements and opportunities for their implementation in the production process leads to an increase in demand for high-performance goods and services. For example, organizations operating in the field of private health care purchase new equipment and materials, providing high-quality medical services (the level of depreciation of fixed assets of commercial health organizations in Russia in 2017 was 38.8\%), while state health organizations use outdated technologies, equipment and materials, as a result, provide medical services of the worst quality (the level of wear and tear of fixed assets of non-commercial health organizations in Russia was 53.6\% in 2017). [10]

Under the pressure of competition and growing demands, this leads to an increase in the resource intensity of providing public goods. In this regard, the priority for nonprofit organizations is to attract financial resources to marketing activities by participating in public and private grants, as well as finding investors.

The sixth factor is the rationalization of the state's economic activity. In an effort to maximize the effectiveness of state property management, modern Russia imposes high and contradictory requirements for the activities of state non-profit organizations (for example, in the health sector). On the one hand, they must provide medical services under the terms of compulsory health insurance (for example, free of charge) without the possibility of further development and formation of an independent pricing policy.

On the other hand, public health organizations should conduct commercial activities, providing medical services on a paid basis, achieving profitability and self-financing. Setting commercial goals for non-profit organizations (as a Supplement to the main non-profit goals related to the performance of their public functions) leads to the priority of profit generation and achieving self-financing. 
It is marketing that provides tools for non-profit organizations to solve various tasks of a business-oriented economy:

- conducting market research that allows you to study current issues and trends in the market situation, as well as monitoring recent changes in demand;

- HR marketing that allows employees of non-profit organizations to form social responsibility;

- investment marketing that allows you to Finance the activities of non-profit organizations as a commercially attractive (profitable) investment project;

- benchmarking, which allows you to identify and analyze the market strategies of competitors, take into account their mistakes and successes. [11]

Thanks to marketing activities, a modern non-profit organization can show high flexibility and adaptability to market changes, maintain its competitiveness at a high level, and maintain self-financing and profitability at a high level. It is marketing that provides a comprehensive achievement of the main non-profit and additional commercial goals that a non-profit organization seeks in today's business-oriented economy.

Thus, thanks to the formation of a business-oriented economy, modern Russia shows features characteristic of deep cultural transformation processes that affect the peculiarities of economic activity. In these new conditions, non-profit organizations face new challenges: increasing resource intensity by reducing their funding and making it more difficult to attract socially responsible employees, while increasing the demand for social responsibility on the part of stakeholders, primarily consumers.

The situation is complicated by the expansion of the presence of commercial organizations in traditionally noncommercial areas of activity, for example, in health care. With globalization, these problems are getting worse and cover more and more areas of the national economy in which non-profit organizations used to dominate. Thus, there are new priorities for marketing non-profit organizations of the organization, the key of which are managing competitiveness and making a profit in the interests of self-financing.

It is obvious that in today's business-oriented economy, the traditional approach to marketing non-profit organizations is ineffective or cannot be applied in principle. Currently, there is a need to develop a new approach to marketing of non-profit organizations, adapted to the peculiarities of the business-oriented economy and corresponding to its current priorities.

This requires the search and application of new, promising technologies and mechanisms for activating and modernizing the marketing activities of non-profit organizations in today's business-oriented economy.

\section{CONCLUSION}

So we can conclude that modern Russian healthcare organizations tend to use marketing technologies in order to actively promote medical services, products and activities of medical professionals. However, there are many problems at all stages of marketing activities related to the lack of investment resources and lack of flexibility of public health organizations, as well as consumer distrust (the complexity of forming brands in this area) and low price competitiveness (due to free alternatives) of private medical organizations. Thus, the lack of consistency in the implementation and use of marketing in health care leads to the practical impossibility of solving current marketing problems. This is primarily due to the separate functioning of public and private health organizations, which leads to the need to combine efforts and establish cooperation (partnership), which, we hope, will help to overcome the gaps that are characteristic of each party and maximize the overall benefits associated with increasing the effectiveness of marketing activities.

\section{REFERENCES}

[1] The Social Responsibility of Non-Profit Organisations A conceptual Approach and Development of SRO model, http://www.observatoritercersector.org/pdf/publicacions /03_rso_en.pdf (дата обращения: 16.10.2017).

[2] VCIOM (Russian Public Opinion Research Center), https://wciom.ru/

[3] Proceedings of the World Economic Forum, https://roscongress.org/materials/otchyet-o-globalnoykonkurentosposobnosti - 2018 goda/

[4] Federal service for surveillance healthcare, http://www.roszdravnadzor.ru/

[5] Kostanyan A.A. Client orientation in public health care: impact on the level of patient satisfaction. // Journal of Marketing in Russia and Abroad, 2018, № 1, 7-13.

[6] Reznik G.A. Positioning strategy of the company based on social-marketing program, Journal of Marketing in Russia and Abroad, 2019, № 5, P. 10-15.

[7] Ben-Ner A. Non-Profit Organizations: Why Do They Exist in Market Economies? In The Economics of Nonprofit Institutions: Studies in Structure and Policy, ed. Susan Rose-Ackerman. Oxford: Oxford University Press. 1986.

[8] Borzenko, K.V., Prziedetzky N.V., Prziedetzky V. Yu, Prziedetzky V.Y. Bondarenko V. A. The Role Of Social-Ethical Marketing And Information And Communication Technologies In Response To Challenges Of Oncology, Scopus, European Research Studies Journal Volume XXI, Special Issue 1, 2018, P. 337-386. 
[11] Savelieva N. A., Kovalenkova O. G., Simonyan T.

[9] Mamsurov A. V. Marketing management in healthcare, Young scientist, 2017, № 22 (156), P. 280282.

[10] Directory of Federal State Statistics Service, http://www.gks.ru/
V. Current trends in the development of medical services on the example of the North Caucasus Federal district. // Science and education: economy and economy; entrepreneurship; law and management. 2019, № 1 (104), Р. 13-18. 